\title{
WHAT MAKES INDONESIA'S SUSTAINABLE INVESTMENT BETTER THAN SHARIAH AND LIQUID?
}

\author{
Indra Gunawan ${ }^{* 1}$, Muhammad Firdaus ${ }^{* *}$, Hermanto Siregar ${ }^{* *}$, and Mulya E. Siregar \\ *) School of Business, IPB University \\ J1. Pajajaran Bogor 16151 \\ ${ }^{* *}$ Departement of Economics and Development Studies, Faculty of Economics and Management, IPB University \\ Jl. Agatis, IPB Dramaga Campus, Bogor 16680
}

\begin{abstract}
This study aimed to compare the performance of SRI-KEHATI, lq45, and JII weekly data set from 2009 to 2020 , covering 100 companies' stocks as members of the indices. Data were standardized within index weighting, followed by non-parametric methods as they were not as susceptible to outliers as the parametric tests were. The performance evaluation used both Kruskal-Wallis and Mann-Whitney U tests. The result showed that SRI- KEHATI had the largest average risk and returns, among others, supported by the fact that investors will choose stocks or indices based on financial aspects and values on ethics, religiosity, and liquidity aspects. It also showed that SRI-KEHATI is best suited for collecting financial, social, and ethical returns at the same time. We also found out from the Mann-Whitney U test that one of the reasons for SRI-KEHATI's performance was due to the major allocation to the four major banks. There was a significant difference between SRI-KEHATI and the performance of the four banks that have been the stock movers all the way, so investors could select the cherry-picking strategy focusing on those stocks instead. This study has managerial implications for investors and fund managers looking for competitive returns amongst three indices where SRI investment is favorable, targeting higher return and awareness of the higher risk and volatilities.
\end{abstract}

Keywords: equity, liquid, non-parametric, sharia, sustainable responsible investment

Abstrak: Penelitian ini bertujuan membandingkan kinerja data mingguan SRI-KEHATI, LQ45, dan JII dari tahun 2009 hingga tahun 2020 yang mencakup total 100 saham perusahaan sebagai anggota indeks untuk mencari kinerja terbaik. Data distandarisasi dalam pembobotan indeks, diikuti dengan metode non-parametrik yang tidak rentan terhadap pencilan seperti halnya uji parametrik. Evaluasi kinerja menggunakan metode tes Kruskal-Wallis dan Mann-Whitney U. Hasil penelitian menunjukkan bahwa SRIKEHATI memiliki rata-rata risiko dan return terbesar antara lain didukung oleh fakta bahwa investor tidak hanya akan memilih saham atau indeks berdasarkan aspek keuangan tetapi juga nilai-nilai pada aspek etika, religiusitas, dan likuiditas. Hasil juga menunjukkan bahwa SRI-KEHATI adalah karena alokasi utama ke 4 saham bank terbesar. Terdapat perbedaan yang signifikan antara SRI-KEHATI dengan kinerja 4 bank yang selama ini menjadi penggerak saham sehingga investor dapat memilih strategi yang berfokus pada saham-saham tersebut. Studi ini memiliki implikasi manajerial bagi investor dan manajer investasi yang mencari pengembalian kompetitif di antara tiga indeks, dimana investasi SRI menguntungkan dengan pengembalian yang tinggi seiring perlunya upaya memitigasi risiko dan volatilitas yang lebih tinggi pula.

Kata kunci: ekuitas, likuid, non-parametrik, syariah, investasi bertanggung jawab berkelanjutan

\footnotetext{
${ }^{1}$ Alamat Korespondensi:

Email: idgunawan@bpkh.go.id
} 


\section{INTRODUCTION}

Investors' stock-picking strategy to diversify and optimize their returns will mix the selection into a composite stock called Index. The equity index is a statistical indicator of changes in the market value of a certain group of shares or stocks (Springer, 2014). There are several types of equity indices, depending on their measurement criteria, such as the coverage base, the averaging method used to establish the index, and the way the averaging methods determine index weights. Therefore, stock indices are not the same, and they may exhibit disparate behavior (Roll, 1992). Investors' effort to maximize their returns and minimize their risk will depend on their knowledge and expertise in selecting stocks or indexes. A few studies have examined the strategy of diversified portfolios (Shan Hu et al. 2010; Al Bakri, 2014).

Investors will choose stocks or indices based not only on the financial aspect but also on non-financial aspects or value investments, such as ethics or Sustainable Responsible Investment (SRI), religiosity as they prefer the Sharia compliance, or even on the liquidity aspect. Moral criteria are often the key determinants for financial decision-making processes (Renneboog and Spaenjers, 2012). The performance of those three indices in Indonesia varies from decade to decade. One of Indonesia's top indices is the SRI-KEHATI (SKEHATI) index that almost consistently outperforms all Indonesia's stock indices, including Jakarta Islamic Index (JII) which represents 30 Sharia equities and the top 45 liquid stocks (LQ45). The Indonesia Stock Exchange (IDX) shows a positive correlation of ESG to higher returns, as the only one of its kind on the IDX. The index is better than the IDX main gauge, the Jakarta Composite Index (JCI), and the LQ45 index in terms of returns between December 30, 2009, and December 30, 2019 , generating a return of 174 percent, outperforming the JCI and the LQ45 index, which generated returns of 149 percent and 104 percent, respectively (Bloomberg Terminal).

SRI-KEHATI consist of 25 stocks with good performance to encourage sustainable businesses, as well as to raise awareness of the environment, social, and good corporate governance complying with SRI principles. SRI-KEHATI Index is in collaboration with the Indonesian Biodiversity Foundation (KEHATI Foundation). The Indonesian Biodiversity Foundation
(KEHATI) was founded on January 12, 1994, and launched in the Jakarta Stock Market on June 8, 2009. It was intended to gather and manage resources to be distributed in the form of grants, facilitation, consultation, and various other facilities to support various biodiversity conservation programs in Indonesia and their use fairly and sustainably.

The role of religiosity investment process occurs in the business and marketing ethics (Hunt \& Vitell, 1992), and a person's religiosity plays a role in the context business ethics (Schneider, Krieger, \& Bayraktar, 2011; Vitell, Singh, \& Paolillo, 2007; Walker, Smither, \& DeBode, 2012). Sharia investments are often considered to be in line with SRI because they both apply ethicalscreening criteria so that they are relevant to the SRI index determinant and the suitability of Sharia and liquidity aspects as variables.

Maqashid Sharia as the Basic Principle requires the maintenance of religion, soul, reason, descent, and wealth or hifz al-maal. The ESG value is an integral part of Sharia or maqashid which seeks to achieve sustainable economic development and overall human welfare (Sairally, 2015). Sharia-compliant investments and stock returns in Indonesia focus on stock returns as one of the indicators to measure equity performance (Sherif and Lusyana, 2016). The Jakarta Islamic Index launched on July 3, 2000, consists of 30 issuers of Sharia-based big caps. JII constituents are all Sharia shares listed on the IDX and are included in the Sharia Securities List (DES) issued by the Indonesian Financial Services Authority (OJK). The JII constituents will be re-elected twice a year, every May and November, following the DES review schedule. In addition to ensuring that the company's performance does not deviate from non-halal activities, OJK also ensures that financial performance is under the principles and conditions permitted in Sharia such as the ratio of debt to total assets (debt to equity ratio) of no more than 45 percent. Then the ratio of interest income and nonhalal income must not exceed 10 percent of the total operating revenue and other income.

The LQ45 Index comprises 45 of the most actively traded stocks with the largest liquidity and market capitalization considerations. The 45 issuers are adjusted every six months (at the beginning of February and August). SRI-KEHATI, JII, and LQ45 all together have become options of investment to maintain and increase the value of life and their assets. Investment 
and activities have become a part or need of today's society. Investors nowadays do not only have risk and return or finance as tools but also value and liquidity aspects to choose from.

Previous studies mostly only compared Sharia and nonSharia performance of Malaysian equities by Maheran and Mochtar (2008), Indonesia mutual funds from 20072014 by Salim, Limakrisna, and Hapzi, (2017), and Saudi Arabian mutual funds by Ashraf (2013). Rangotra (2016) compared the risk and return of traditional and SRI of Asia and India, while Hatem (2016) compared the performance of the Canadian SRI mutual fund. The main contribution of this paper is not only comparing the two but also combining the assessment of the differences in the return and the risk between the three indices to fill the research gap. How to choose the best return and risk between SRI-KEHATI, Syariah, or liquid stocks in Indonesia. 2. How to differ the performance of SRI-KEHATI, Sharia, or liquid stocks in Indonesia. 3. How to dissect the weight of certain shares on the best performance index in Indonesia. 4. How to differ the performance of SRI-KEHATI, and the weighting to have the best index performance. The results are expected to reduce the gap in the investment literature focusing on the performance comparison, as well as to differ the influence of the stock weighting on the performance of the index.

SRI's portfolio analysis by Statman and Glushkov (2009) shows that the application of different SRI criteria influences investment styles differently. Luther et. al. (1994), Luther and Matatko (1994), and Scholtens (2005) show that SRI mutual funds are leaning towards small caps. Schroder (2004), Bauer et. al. (2005), Gregory and Whittaker (2007), and Cortez et. al. (2009) observed the European SRI fund performance and Cortez et. al. (2011), extending the comparison between the US and European SRI, found a small and growth cap bias (small stocks and growth stocks) associated with SRI mutual funds. Studies by Kurtz and DiBartolomeo (2011), and Statman (2006) show that the Domini Social Index (DSI 400), formed in 1990, was changed to MSCI KLD 400 Social Index in 2010 which tends to be more exposed to growth stocks than the conventional Index Growth S\&P 500. This is consistent with Kempf and Osthoff (2007) and Statman and Glushkov (200) showing that the SRI portfolio tends to lean towards growth stocks. Zulkafli et. al. (2017) use the risk-adjusted returns of Sharpe, Treynor, Jensen's Alpha Index, and Sortino's Ratio to examine the comparative performance of SKEHATI and JCI.

SKEHATI proved to have outperformed JCI during the overall period from 2009 to 2014. As there is a contradiction between the adjusted returns of Sharpe's Index/Adjusted Sharpe's Index and Jensen's Alpha Index, the hypothesis that the SKEHATI presents a higher risk-adjusted performance than the JCI cannot be accepted. Even though the performance of SKEHATI in this study is slightly lower over the whole period of the study, it is still generating competitive returns. In addition to having outperformed JII and LQ45, SKEHATI also exceeded the commitments of the international Sustainability DevelopmentGoals(SDGs), even exceeding what is stated in the Sustainable Stock Exchange (SSE) initiatives launched by the United Nations (UN) through the United Nations Conference of Trade and Development (UNCTAD), the United Nations Environment Program Finance Initiative (UNEP-FI), and the Principles for Responsible Investment (PRI). On top of the social benefits, it has also gained other benefits from an investment perspective. Through the SSE initiative, the stock market index considers not only the financial aspects, but also the environmental, social, and governance or ESG aspects in the listing rules and regulatory framework in the stock market.

In general, the SRI index must follow a continuous investment cycle not merely to obtain short-term returns. The sustainable investment cycle is based on the proposition of the combination of socio-cultural, educational, economic, technical, and climate factors to form complex causal patterns that affect the effectiveness of sustainable projects in the community (Parnell and Seemann, 2005). It has a selection process based on Environmental, Social, and Governance (ESG) criteria as a reference for choice in which investors will decide whether to invest or not.

Comparative research of Sharia and SRI stock portfolios by Hassan et. al. $(2005,2010)$ and Abderrezak $(2008)$ shows that the Islamic investment portfolios appear to be more exposed to small companies and growth. Merdad et. al. (2010) find that regardless of the benchmarks used, whether Islamic or conventional, the systematic risk of Islamic funds is always lower than their conventional counterparts during financial crises. Zulkafli et. al. (2017) mentioned the possible link between SKEHATI performance and other behavioral finance. Specific study on members and weighing on 
the index, Achsani et. al (2019) concluded there are five of eight independent variables that significant influence on the stock price at the LQ45 of coal issuers, and there are four of nine independent variables that significant influence on the stock price at the nonLQ45 of coal issuers.

To shed more light, future studies on other ethical aspects such as religiosity because Indonesia is the most Muslim populated country in the world need to be conducted. Comparative performance of Islamic or Sharia funds/indices, which are also identified as another kind of SRI with a liquidity aspect, will enrich the options of the investors since not all ethical finance is following the rules and requirements of Sharia. However, Sharia and compliant investment have to be ethical.

\section{METHODS}

This research observes stock members and prices within three indices from June 1999 to June 2020 in Indonesia Stock Exchange. 25 stocks of the SRIKEHATI Index, 30 stocks of Jakarta Islamic Index (JII), and 45 stocks of LQ45. Data were obtained from the Bloomberg terminal based on weekly price movement and index weighting. The non-parametric approach is rarely used to test stock performance, especially using standardized weekly stock prices where data processing and weightings are applied to take out some out-layers. The stages of calculating index weighting proceed with five operational steps.

Step 1 Calculate the index weighting

$$
\mathrm{w}_{\mathrm{it}}=\mathrm{Y}_{\mathrm{it}} / \sum \mathrm{Y}_{\mathrm{it}}
$$

Description: $\mathrm{w}_{\text {it }}$ (weighting of stock to $\mathrm{i}$ and time to $\mathrm{t}$ ); $Y_{i t}($ value of shares of the issuer to $i$ and time to $t$ ).

Step 2 Calculate the value of a stock that has been weighted

$$
\mathrm{Y}_{\mathrm{it}}^{\prime}=\mathrm{w}_{\mathrm{it}} \times \mathrm{Y}_{\mathrm{it}}
$$

Step 3 Count the number of stocks at one period of time

$$
n_{i}=i \sum_{i=1}^{n} X i t
$$

Description: Xit (stocks at $\mathrm{i}$ and time to $\mathrm{t}$ )
Step 4 Calculate the Index Weighting value

$$
\text { Index weighting }(t)=i \frac{\sum_{i=1}^{n} Y_{i t}^{\prime}}{}
$$

Step 5 Calculate the normalization of Index weighting

$$
\text { Index weighting(standardize })=i \frac{\sum_{i=1}^{n} Y_{i t}^{\prime} i}{\sum_{i=1}^{n} Y_{i 1}^{\prime} i}
$$

The design of this study is to compare the average difference test with non-parametric methods. Nonparametric methods applied to anticipate outliers and smoothen examination. One outlier score will affect the parametric test by inflating the variance and the error term. This can invalidate the conclusion drawn by the parametric test so that you can make a type 1 error or perhaps even a type 2 error. The correlating outliers can change the direction or the strength of a relationship between variables. Non-parametric tests do not have this limitation because they measure central tendency using ranked data. The ranking uses the median rather than the mean.

The main advantage of non-parametric statistics is that they do not require restrictive assumptions about the distribution. Non-parametric tests can also be used when you have non-normal interval or ratio data such as highly skewed data. The requirements for using the parametric method are that the data must be normally distributed, and if they meet the assumptions that the data are spread normally, the performance evaluation of each index continues with the one-way ANOVA test. If the results of the normal test are not met, the testing method is approached using the non-parametric test.

The framework of the research applies the KruskalWallis, inspired by Siegel (1971) on the quartile performance of the companies and industrial sectors, monthly market price, and volatility with multifactor models (Rashid and Radiah, 2017). The Kruskal Wallis test is also applicable to explore the significance of such a seasonality in stock price behavior as a Debashis' (2018) analysis on the Indian stock market employing the daily price series of seven selected IT companies. A previous study by Brooks and Persand (2001) using the Kruskal Wallis test examined the evidence for the days of the week effect in five Southeast Asian stock markets including Taiwan, South Korea, the Philippines, Malaysia, and Thailand compared to the major stock indices used in each country. Jordão and de Almeida (2017) examined an expanded annual assessment performance measurement with the profitability 
indices: EBITDA, NPM, and GM, and return indices: ROIC, ROA, and ROE. These indices present higher returns and risks than other indices, using the KruskalWallis test presented in Table 1 (descriptive analysis). If the Kruskal-Wallis test results are significant, then it can be continued with the Mann-Whitney U test, to further observe the differences between groups. The hypothesis used is as follows.

$\mathrm{H} 0: \mu 1=\mu 2=\mu 3$

$\mathrm{H1}$ : at least there are a pair of groups that are significantly different.

This next step applies a non-parametric test, namely the Mann-Whitney U test, to compare the difference between sustainable equity performance and market capitalization according to the size of the bank (Schildbach, 2017), which is consistent with prior research of some large banks in the adoption of sustainable practices (Kaur, 2018).

\section{RESULTS}

\section{Descriptive Analysis}

The results of the descriptive analysis include the average value, the standard deviation, the minimum and maximum values of each index, the average and median index data, and the risk value illustrated by the amount of the standard deviation. It can be summarized that the SKEHATI index has the highest index value of 5.0526 with a level of risk that is also high with a standard deviation of 2.9373 , the highest between the LQ 45 and JII indices.

SRI-KEHATI as one of the ethical and sustainable investment indexes in Indonesia has consistently outperformed religious equity (JII) and liquid stocks (LQ45) since 2009, where the median and standard deviation of the LQ 45 index is 2.75446 and 0.8992 , and the JII index with a median and standard deviation of 1.7218 and 0.3053 . The greater risk in the SKEHATI index is compensated by the high return. This also reclaims the general rule of high risk equals high return and vice versa. Further statistical difference test after the descriptive analysis shows that the SKEHATI index is riskier and at the same time provides a higher level of profit than LQ 45 and JII.

\section{Normal Results}

Before we analyze whether there is a difference in the performance of the index between SKEHATI, LQ 45, and JII, we need to test the data first. If the data are normally distributed and homogeneous, we will proceed with the one-way ANOVA which is a parametric statistic. However, if the data are not normally distributed, we shall proceed with the Kruskal-Wallis non-parametric test. Normality test presented in Table 2.

Table 1. Descriptive Analysis

\begin{tabular}{lcccccc}
\hline Indices & $\mathrm{N}$ & $\mathrm{Mean}$ & Median & Std. Deviation & Minimum & Maximum \\
\hline SKEHATI & 577 & 5.5769 & 5.0526 & 2.9373 & 0.8653 & 13.3909 \\
LQ-45 & 577 & 2.9146 & 2.7544 & 0.8992 & 0.9500 & 5.2307 \\
JII & 577 & 1.7847 & 1.7218 & 0.3053 & 0.9309 & 2.7317 \\
\hline
\end{tabular}

Table 2. Normality Test

\begin{tabular}{llccc}
\hline One-Sample Kolmogorov-Smirnov Test & & SKEHATI & LQ 45 & JII \\
\hline $\mathrm{N}$ & & 577 & 577 & 577 \\
Normal Parameters b,c & Mean & 5.5769 & 2.9146 & 1.7847 \\
& Std. Deviation & 2.9373 & 0.8992 & 0.3053 \\
Most Extreme Differences & Absolute & .103 & .098 & .109 \\
& Positive & .103 & .098 & .109 \\
& Negative & -.084 & -.056 & -.064 \\
Test Statistic & & .103 & .098 & .109 \\
Asymp. Sig. (2-tailed) & & .000 & .000 & .000 \\
\hline
\end{tabular}




\section{Kruskal-Wallis Test Results}

The results of the descriptive statistics, extended by the Kruskal-Wallis tests in Table 3. As there are 3 samples of this study, we use the Kruskal-Wallis in testing the hypothesis. The Kruskal-Wallis test is used in the comparative analysis to test more than two independent samples, provided that the number of samples is not the same, and the three samples do not affect each other (Jordão and de Almeida, 2017). This test is to determine whether there are differences between the three samples. The test criteria are taken based on the probability value (Sig.): 1) if the probability value is (Sig.) $>0.05$, Ho is accepted, and 2) if the probability value is (Sig.) $<0.05$, Ho is rejected.

Table 3. Kruskal Wallis Test Results

\begin{tabular}{lc}
\hline & Test Statistics a,b \\
\hline & Indices \\
\hline Chi-Square & 970.596 \\
Df & 2 \\
Asymp. Sig. & .000 \\
\hline
\end{tabular}

a. Kruskal Wallis Test; ${ }^{\text {b. }}$ Grouping Variable

The result in the Table 3 show that the probability value is (Sig.) $=0.000$, or (Sig.) $<0.05$, so Ho is rejected. Therefore, it can be concluded that there are differences in performance as measured by the indexes of the three groups namely SKEHATI, LQ45, and JII. The results of the Kruskal-Wallis test can also be seen as the mean rank of each group; the mean rank results can indicate which index group is the highest and which is the lowest. The synthesis of the results complements previous studies (Mendoza, 2017; González et al. 2017) to further study on the positive contribution of stock performance to SKEHATI. These results were observed in statistical tests (descriptive statistics, Kruskal-Wallis, and MannWhitney mean rank tests). Also, such findings reveal that more exposure to 4 banks will increase the returns of SKEHATI.

The results in Table 4 show the Mann-Whitney U test with subsets $(a, b$, and $c)$. The subsets show the differences between the three groups namely SKEHATI (c), LQ45 (b), and JII (a). The different subsets mean a significant difference index, and that SKEHATI mean Index is the most significant difference index among others.

The results from Table 4 show that the best performance is still SKEHATI's index. This typical result was revealed by Vermeir et. al. (2005), and the SRI index tends to be filled with big caps. Schroder (2004) and Bauer et. al. (2005) have found that while the European SRI mutual funds tend to be biassed towards small caps, the US SRI mutual funds tend to take big caps and perform better. We find that there are 4 big banks with $54.2 \%$ of the total market share in SRI KEHATI, which consist of BBCA (28.2\%), BBRI (14.1\%), BMRI $(8.9 \%)$, and BBNI $(3.0 \%)$ that have not only been the leading movers but also the majority weighting in the index (Table 5).

\section{Comparison of SKEHATI Index vs 4 banks}

We analyzed the results of the difference test between SKEHATI and the performance of 4 banks using the Mann-Whitney U test. The results of the MannWhitney $U$ test show that the probability value $(0,000)$ is smaller than alpha $5 \%$, meaning that there is a significant difference between the SRI index and the performance of the 4 banks. The 4 banks' performance almost a triple time of SKEHATI's performance. The results from Table 6 show that the best performance is still SKEHATI's index.

The key challenge for investors in the financial markets is how to choose between financial instruments that represent the financial, social, and ethical needs of different investors. The purpose of this paper is to differentiate the performance of SRI, Sharia, or liquid stocks in Indonesia. This study finds that a significant and complementing examination of SRI performance in emerging countries contributes to the improvement of investment theory and practice and provides a competitive benchmarking process. This makes it possible for investors and regulators to evaluate stocks, indices, and the market as a whole employing options between financial or ethical choices.

Table 4. Mean rank table

\begin{tabular}{lcccc}
\hline Group & $\mathrm{N}$ & Mean Rank & Median & Std. Deviation \\
\hline SKEHATI & 577 & $1294.52^{\mathrm{a}}$ & 5.0526 & 2.9373 \\
LQ-45 & 577 & $920.84^{\mathrm{b}}$ & 2.7544 & 0.8992 \\
JAKISL & 577 & $382.64^{\mathrm{c}}$ & 1.7218 & 0.3053 \\
\hline
\end{tabular}


Table 5. Members of SRI KEHATI Index

\begin{tabular}{llc}
\hline SKEHATI Index & & Meight (\%) \\
\hline BBCA & Bank Central Asia Tbk PT & 28.2 \\
BBRI & Bank Rakyat Indonesia Persero Tbk PT & 14.1 \\
TLKM & Telekomunikasi Indonesia Persero Tbk PT & 12.8 \\
UNVR & Unilever Indonesia Tbk PT & 11.4 \\
BMRI & Bank Mandiri Persero Tbk PT & 8.9 \\
ASII & Astra International Tbk PT & 6.8 \\
BBNI & Bank Negara Indonesia Persero Tbk PT & 3.0 \\
UNTR & United Tractors Tbk PT & 2.6 \\
INDF & Indofood Sukses Makmur Tbk PT & 2.3 \\
KLBF & Kalbe Farma Tbk PT & 2.2 \\
SMGR & Semen Indonesia Persero Tbk PT & 2.0 \\
JSMR & Jasa Marga Persero Tbk PT & 0.9 \\
PGAS & Perusahaan Gas Negara Tbk PT & 0.8 \\
SIDO & Industri Jamu Dan Farmasi Sido Muncul Tb & 0.8 \\
BSDE & Bumi Serpong Damai Tbk PT & 0.7 \\
AALI & Astra Agro Lestari Tbk PT & 0.5 \\
JPFA & Japfa Comfeed Indonesia Tbk PT & 0.4 \\
WIKA & Wijaya Karya Persero Tbk PT & 0.4 \\
BBTN & Bank Tabungan Negara Persero Tbk PT & 0.4 \\
WSKT & Waskita Karya Persero Tbk PT & 0.3 \\
TINS & Timah Tbk PT & 0.2 \\
PPRO & PP Properti Tbk PT & 0.1 \\
WTON & Wijaya Karya Beton Tbk PT & 0.1 \\
ADHI & Adhi Karya Persero Tbk PT & 0.1 \\
PJAA & Pembangunan Jaya Ancol Tbk PT & 0.0 \\
\hline
\end{tabular}

Table 6. Mann-Whitney U test results

\begin{tabular}{lc}
\hline \multicolumn{2}{c}{ Test Statistics } \\
\hline & Indices \\
\hline Mann-Whitney U & 97711.500 \\
Wilcoxon W & 250892.500 \\
$Z$ & -10.391 \\
Asymp. Sig. (2-tailed) & .000 \\
Grouping Variable & \\
\hline
\end{tabular}

Considering that previous studies have not been able to explain how to compare equity indices based on financial or ethical choices, this paper attempts to fill this gap utilizing a quantitative, descriptive, and applicative study. Since the data are not distributed normally, the Kruskal-Wallis test is applied following Siegel (1971) on the quartile performance of the monthly market prices of companies and the industrial sector as well as volatility with multifactor models (Rashid and Radiah 2017). While most authors base their studies on quarterly data, this study compares multi equity indices weekly from 2009 to 2020, using descriptive and non- parametric tests. The results complement previous SRI equity studies (Mendoza, 2017; González et al. 2017) regarding the positive contribution of stock performance to SKEHATI. The research by Vermeir et. al. (2005) shows that the SRI index tends to be filled with big caps, in line with the research by Schroder (2004) and Bauer et. al. (2005). The index mover measures are consistent with Achsani (2019). We can also consider a similar study using the pooled and day-of-the-week effects of night and daytime returns in the US equity indices by Monteiro and Manso (2018) between three indices using the dummy crisis and non-crisis instead of the parametric and non-parametric tests for the equality of means and variances and individual stock index and panel data regression-based approaches for further research.

The results of this research reduce the gap in the investment literature that focuses on the performance and differ the non-parametric test with several methodologies. In addition to the range and depth of 
the statistical tests, attention should be drawn to the originality of the research questions. This paper has proved to be valid and significant, complementing the examination of SRI performance in Indonesia and providing a competitive benchmarking process. This makes it possible for investors and regulators to evaluate stocks, indices, and the market as a whole through providing options between financial or ethical choices.

\section{Managerial Implication}

The study has managerial implications for investors and fund managers looking for competitive returns amongst three indices where SRI investment is favorable targeting higher return or even asset focusing only on 4 banks for optimal weighting. Decision-makers can provide stimuli for SRI Investment so that the investor foundation becomes wider, covering institutional or individuals to strengthen Indonesia's financial inclusion as well as deepening capital markets. This is to strengthen the fundamentals economy and market independence.

\section{CONCLUSIONS AND RECOMMENDATIONS}

\section{Conclusions}

The analysis supports some major conclusions, namely that SRI outperforms other indices significantly, demonstrating higher rates of return and risk than other indices. We also learn that there is a significant difference between SKEHATI and the performance of 4 banks using the Mann-Whitney U test so that investors can choose a cherry-picking strategy focusing on these stocks. The policy implication of the study is expected to help investors in choosing the optimal performance among SRI, Sharia, or liquid stocks in Indonesia. The significant difference shows that SRI-KEHATI is the most suitable one that collects financial, social, and ethical returns at the same time. The implication for the government is the ability to endorse ESG aspects in the listing rules and regulatory framework on the stock market, to promote SRI investment in the financial industry, to enrich literature that explains some influences on investors' decisions in choosing SRI as organizational and managerial behaviors.
The fact that banking stocks increase the performance of SRI-KEHATI systematically over time is an interesting topic for further research. This research helps investors and investment managers searching for attractive returns across three indices where SRI index is optimal for higher returns and is also cautious of higher risk and volatility. Theoretically, this is relevant to the 'high risk and high return' philosophy and to better understand the effects on sustainable investment and its performance from Indonesia's perspective. Empirically, SRI will be an option for investors aiming for diversification under the financial or non-financial (moral) differentiation compared to other indices since there is no option to combine all options. Although another challenge to answer is whether the bank's performance is liquid and sustain during a market crisis, where it has been confirmed that the bank is not following sharia law.

\section{Recommendations}

The first limitation is that the research objective is not to make a new mixed index between the three and only compare return-risk the three indices. Whereas some stocks probably are members of those three indices at the same time. The dataset only represents a sample of the Indonesian market not globally. Therefore, we recommend further research by extracting inferences to the broader market for broader investors. The second limitation is that we have not taken into account different economic situations and their impact on the volatility. There are some bullish and bearish trends and fluctuations in between that may have various correlations for each stock and indices to have an optimal return in the long run as our second recommendation.

\section{REFERENCES}

Achsani NA, Tubagus, NAM, Asysyifa V. 2019. The Effect of Company Financial Performance and Macroeconomic Variables to the Stock Price of Coal Mining, Comparison between LQ45 and Non-LQ45. Jurnal Aplikasi Manajemen dan Bisnis 5(3): 348-360

Al Bakri, Anas 2014. Portfolio Diversification Strategy and the Impacts on the Middle East Real Estate Investment Decision. International Journal of Economics and Finance 6(2): 62-74. 
Bauer R, Koedijk K, Otten R. 2005. International evidence on ethical mutual fund performance and investment style. Journal of Banking and Finance 29 (7): 1751-1767.

Cortez MC, Silva F, Areal N. 2009. The performance of European socially responsible funds. Journal of Business. Ethics 87(4): 573-588.

Cortez MC, Silva F, Areal N. 2011. Socially responsible investing in the global market: the performance of US and European funds. International Journal of Finance \& Economics 17(3): 254271.

Gregory A, Whittaker J. 2007. Performance and performance persistence of 'ethical unit trust in the UK. Journal of Business Finance and Accounting 34(7-8): 1327-1344.

Hassan A, Antoniou A, Paudyal DK. 2005. Impact of ethical screening on investment performance: the case of the Dow Jones Islamic Index. Islamic Economic Studies 12(13): 2/1.

Hassan MK, Khan ANF, Ngow T. 2010.iIs faith-based investing rewarding? The case for Malaysian Islamic unit trust funds. Journal of Islamic Accounting \& Business Research, 1(2):148171.

Hatem Ben-Ameur, Ayadi MA, Kryzanowski, 2016. Typical and Tail Performance of Canadian Equity SRI Mutual Funds, Lawrence. Journal of Financial Services Research; Dordrecht 50(1):57-94.

Kaur S. 2018. A study on the impact of CSR performance on the financial performance of Indian service sector, International Journal of Business Competition and Growth 6(2): 115-127.

Kempf A, Osthoff P. 2007. The effect of socially responsible investing on portfolio performance. European Financial Management 13(5): 908922.

Luther RG, Matatko J. 1994. The performance of ethical unit trusts: choosing an appropriate benchmark. British Accounting Review 26(1): 77-89.

Maheran NM, Mokhtar M. 2008. Islamic equity mutual fund performance in Malaysia. Risk and Return Analysis Journal 3: 15-23.

Mendoza RR. 2017, Relationship between intangible assets and cash flows: an empirical analysis of publicly listed corporations in the Philippines. Review of Integrative Business and Economics Research 6(1):188-202.

Merdad H, Hassan MK, Al-Henawi Y. 2010, Analysis of Islamic versus conventional mutual funds in Saudi Arabia. Journal of King Abdul Aziz University, Islamic Economics 23(2): 161-198.

Monteiro JD, Manso JRP. 2018. Are there night and daytime effects in us equity indices returns? a robust econometric analysis. Journal of Economic \& Management Perspectives; Mersin 12(2):189-207

Rangotra R. 2016. Analysis of risk and return of traditional and socially responsible investing (SRI): an empirical study of Asia and India. Advances in Management Indore 9(3): 1-5.

Rashid A, Othman R. 2017. Corporate social responsibility performance communication and portfolio management, Managerial Finance Patrington 43(5): 595-613

Renneboog L, Spaenjers C. 2012. Religion, economic attitudes, and household finance. Oxford Economic Papers 64(1): 103-127.

Roll R. 1992. Industrial structure and the comparative behavior of International Stock Market Indices. Journal of Finance 47(1): 3-41.

Sairally S. 2015. Integrating Environmental, Social and Governance (ESG) Factors in Islamic Finance: Towards the Realisation of Maqāṣid al-Sharī'ah. ISRA International Journal of Islamic Finance 7: 145-154.

Salim AM, Limakrisna N, Ali H. 2017. Mutual funds performance: conventional and shariah product. International Journal of Economics and Financial Issues; Mersin 7(4): 26-38

Schildbach J. 2017. Large or small? How to measure bank size, Deutsche Bank Research, 1-23

Schneider H, Krieger J, Bayraktar A. 2011. The impact of intrinsic religiosity on consumers' ethical beliefs: does it depend on the type of religion? a comparison of christian and moslem consumers in Germany and Turkey. Journal of Business Ethics 102(2): 319-332

Scholtens B. 2005. Style and performance of dutch socially responsible investment funds. The Journal of Investing 14(1): 63-72.

Schroder M. 2004. The performance of socially responsible investments: investment funds and indices. Financial Markets and Portfolio Management 18(2): 122-142.

Shan Hu, John Wei, Yue Chin Chen, 2011. The performance of momentum investment strategies. An International Examination of Stock Markets, International Journal of Management, 28 (4): 165-195.

Sherif M, Luciana D. 2016, Shariah-compliant 
investments and stock ret: evidence from the Indonesian stock market, Journal of Islamic Accounting and Business Research 8(2): 1-27.

Sparkes R. 2002. Socially Responsible Investment, A Global Revolution. The Athrium, Southern Gate Chichester, West Sussex, England: John Wiley \& Sons

Springer. 2014. Encyclopedia of Quality of Life and Well-Being Research, 2014 Edition

Statman M. 2006. Socially responsible indexes: composition, performance, and tracking error. Journal of Portfolio Management 32(3): 100109.

Statman M, Glushkov D. 2009. The wages of social responsibility. Financial Analysts Journal 65(4): 33-46.
Vermeir W, Velde E, Corten F. 2005. Sustainable and responsible performance, Journal of Investing Fall, 94-100.

Vitell SJ. Singh JJ, Paolillo JGP. 2007. Consumers' ethical beliefs: The roles of money, religiosity, and attitude toward business. Journal of Business Ethics 73(4):369-379.

Walker AG, Smither JW, DeBode J. 2012. The effects of religiosity on ethical judgments. Journal of Business Ethics 106(4): 437-452

Zulkafli AH, Zamri A, Eky EM. 2017. The performance of socially responsible investments in indonesia: a study of the SRI-KEHATI Index (SKI). Gadjah Mada International Journal of Business 19(1): 59-76 